\title{
EKSTERNALITAS POSITIF TAMBANG BATUBARA TERHADAP KESEJAHTERAAN SOSIAL EKONOMI MASYARAKAT DI KABUPATEN KUTAI KARTANEGARA
}

\author{
Muhammad Suciadi ${ }^{1}$, Eko Priyo Purnomo², Aulia Nur Kasiwi ${ }^{3}$
}

\author{
1)2)3) Universitas Muhammadiyah Yogyakarta \\ eko@umy.ac.id
}

Received: 8 June $2020 \quad$ Reviewed: 9 June 2020 | Accepted: 13 July 2020

\begin{abstract}
ABSTRAK
Kabupaten Kutai Kartanegara, Merupakan daerah yang memproduksi batubara terbanyak di Provinsi Kalimantan timur pada tahun 2017 di produksi perusahaan pemegang izin usaha pertambangan (IUP). Kabupaten Kutai Kartanegara juga menerima Dana Bagi Hasil (DBH) batubara terbesar kedua di Provinsi Kalimantan Timur dengan jumlah Rp2,860 triliun. Produksi tambang batubara sendiri tidak hanya berdampak positif terhadap ekonomi Daerah namun juga berdampak terhadap ekonomi Lokal tempat produksi batubara tersebut dilakukan. Sehingga peneliti akan mencari tahu apa sajakah dampak positif yang ditimbulkan oleh Perusahaan tambang batubara terhadap sosial ekonomi masyarakat yang berada di lingkungan sekitar tambang batubara di Kabupaten Kutai Kartanegara pada tahun 2019. Metode yang di gunakan dalam penelitian ini menggunakan tipe dan jenis penelitian kualitatif dengan pendekatan deskriptif, adapun data studi didapatkan melalu analisis dokumen, media dan pustaka. Data dalam studi ini dianalisis menggunakan teknik trigangulasi data. Hasil dalam penelitian ini ialah. Pertama, Hadirnya Sektor pertambang di Kabupaten Kutai Kartanegara banyak memberikan dampak positif terhadap linggkungan sosialnya seperti semakin ramainya jumlah penduduk yang berwirausaha di sekitar lingkungan pertambangan. Kedua, meningkatnya kegiatan sosial dalam lingkup masyarakat karena adanya pembangunan infastruktur oleh sektor perusahaan. Ketiga, menunjang pendapatan daerah di sebabkan oleh sektor tambang yang merupakan komoditas yang mendominasi dalam bidang ekonomi dan meningkatnya pendapatan perkapita masyarakat karena semakin luasnya penyerapan ketenagakerjaan yang tersedia oleh perusahaan tambang batubara. Sehingga dengan pertumbuhan ekonomi yang tercipta oleh adanya perusahaan tambang batubara tersebut dapat menjadi penunjang kesejahteraan masyarakat sekitar.
\end{abstract}

Kata Kunci: Eksternalitas Positif, Tambang Batubara, Sosial Ekonomi

Korespondensi:

Universitas Muhammadiyah Yogyakarta Jl. Brawijaya, Geblagan, Tamantirto, Kecamatan. Kasihan, Bantul, Daerah Istimewa Yogyakarta 


\begin{abstract}
Kutai Kartanegara Regency, is the most coal producing region in East Kalimantan Province in 2017 in the production company holding a mining business permit (IUP). The District of Kutai Kartanegara also received the second largest Coal Production Sharing Fund (DBH) in East Kalimantan Province with a total of Rp2,860 trillion. Coal mining production itself not only has a positive impact on the regional economy but also has an impact on the local economy of coal production undertaken. Looking for researchers will find out what are the positive impacts caused by coal mining companies on the socio-economic community in the environment around coal mines in Kutai Kartanegara Regency in 2019. The method used in this study uses the types and types of qualitative research by discussing, as for Study data obtained through analysis of documents, media and libraries. Data in this study were analyzed using data trigangulation techniques. The results in this study are. First, the presence of the mining sector in Kutai Kartanegara Regency has had more positive impacts on its social environment, such as the increasing number of people who are entrepreneurs in the vicinity of the mining environment. Second, discussing social activities in relation to the community because of the infrastructure development by the corporate sector. Third, supporting regional income is caused by the mining sector which represents commodities in the economic sector and increasing income per capita in the community because of the wider transportation of labor provided by coal mining companies. Realizing economic growth created by coal mining companies can support the welfare of the surrounding community.
\end{abstract}

Keywords: Positive Externality, Coal Mining, Socio Economic

\title{
PENDAHULUAN
}

Tulisan ini membahas tentang eksternalitas positif yang di timbulkan oleh perusahaan tambang batubara. Sektor pertambangan batubara di Indonesia merupakan salah satu sektor industri utama dalam bidang ekonomi. Indonesia sendiri merupakan salah satu negara produsen dan eksportir batubara terbesar di posisi ke-5 sejak tahun 2005 (Rikhza Hasan, 2019). Sehingga batubara menjadi salah satu sector penyumbang devisa negara hingga 36\% dari pendapatan negara pada tahun 2008 kementrian ESDM, 2009 dalam pertiwi 2011 dalam (Apriyanto \& Harini, 2012). Pada bulan januari-november 2018 ekspor batubara tumbuh 7,22\% menjadi 312,3 ton dari periode yang sama pada tahun sebelumnya.

Pengembangan produksi dalam sector ini tentunya sangat tergantung dengan sumber daya alam yang ada di daerah. Sumber daya alam yang melimpah di tambah pengelolaan yang baik maka akan dapat menghasilkan hasil produksi yang baik pula. Salah satu daerah yang memiliki sumber daya alam yang melimpah dalam bidang ini ialah Kalimantan Timur yang lebih tepatnya di kabupaten kutai kartanegara. Daerah tersebut memiliki potensi yang sangat besar dalam bidang ekonomi dari komoditi batubara. Pada tahun 2017 Kabupaten Kutai 
kartanegara memproduksi batu bara terbanyak di provinsi Kalimantan timur yaitu sebesar 82,87 juta ton dari total produksi perusahaan pemegang izin usaha pertambangan (IUP) dan pada tahun 2018 Kabupaten Kutai Kartanegara memproduksi batubara naik mencapai $86,989,488.38$ per metrix ton (MTon) (Purbondari \& Dewi Intansari, 2020) dan juga Kabupaten Kutai Kartanegara menerima Dana Bagi Hasil (DBH) batubara terbesar kedua di Provinsi Kaltim dengan jumlah Rp2,860 triliun (Intoniswan, 2020).

Keberadaan tambang batubara sendiri sering menjadi kontroversi baik di kalangan pemerintah maupun masyarakat. Hal tersebut di sebabkan oleh dampak negatif yang di timbulkan oleh pertambangan batubara terhadap lingkungan yang banyak di rasakan oleh masyarakat sehingga menimbulkan stigma-stigma negatif yang keluar dari kalangan masyarakat terhadap perusahaan pertambangan (Hendry, n.d.). Pemikiran negatif tersebut seakan memberi penilaian yang kurang baik terhadap sebuah perusahaan pertambangan. Padahal nyatanya secara tidak langsung perusahaan pertambangan batubara tidak hanya menciptakan dampak negatif saja tetapi juga menciptakan dampak positif. Banyak dampak positif yang di ciptakan oleh perusahaan tambang batubara untuk kesejahteraan masyarakat. Salah satunya adalah meningkatkan perekonomian daerah, namun tambang batubara sendiri tidak hanya berdampak positif terhadap ekonomi daerah tetapi juga berdampak terhadap ekonomi lokal tempat produksi batubara tersebut dilakukan. Dampak tersebut pun secara tidak langsung dapat di rasakan oleh masyarakat yang bertempat tinggal di sekitar lingkungan pertambangan seperti tersedianya lapangan pekerjaan, fasilitas sosial, fasilitas umum dan meningkatnya pendapatan Usaha Mikro Kecil Menengah (UMKM) masyarakat sekitar tambang batubara (Nggeboe.SH, 2004). Seperti halnya yang terjadi di kabupaten kutai kartanegara dimana mayoritas penduduk atau masyarakatnya memiliki ketergantungan ekonomi terhadap sektor pertambangan batubara tersebut karena sebagian masyarakatnya bekerja sebagai karyawan tambang batu bara dan sebagian lainya bekerja sebagai berdagang atau pengusaha UMKM yang diamana pendapatanya juga sangat di pengaruhi oleh kegiatan sector pertambangan (Apriyanto \& Harini, 2012).

Bedasarkan beberapa uraian penjelasan di atas maka peneliti akan melakukan penelitian dalam sektor pertambangan batubara yang dimana peneliti akan mencari tahu apa sajakah dampak positif yang di timbulkan oleh perusahaan tambang batubara terhadap sosial ekonomi 
masyarakat yang berada di lingkungan sekitar tambang batubara di Kabupaten Kutai kartanegara pada tahun 2019. Sehingga harapanya hasil dari penelitian ini dapat menambah wawasan kepada kita semua mengenai dampak-dampak positif yang di ciptakan oleh perusahaan tambang batubara dan dapat mengubah stigma negatif atau penilaian yang kurang baik terhadap sektor pertambangan.

Litelatur Review, Dalam mencari relasi untuk penelitian mengkaji studi terdahulu dengan topik yang relevan dengan penelitian merupakan sebuah keniscayaan. Hal ini berguna untuk memberikan kejelasan pemahanan terhadap penyusun dan memberikan batasan atau fokus penelitian yang akan diteliti. Selain itu, mengkaji studi terdahulu dengan topik yang relevan juga akan berguna untuk memastikan orisinalitas bahwa penelitian yang berjudul "Eksternalitas Positif Tambang Batubara Terhadap Kesejahteraan Ekonomi Sosial Masyarakat Di Kabupaten Kutai Kartanegara Tahun 2019” adalah berbeda dan belum pernah dibahas ataupun diteliti sebelumnya.

Dalam hal ini peneliti menggunakan 15 literatur review sebagai relasi dalam penyusunan penelitian yang berbeda, yaitu : Menurut Sandra (2015), Dampak eksternalitas dari sebuah peusahaan dapat di lihat dari perubahan masyarakat sosial di lingkungan sekitar yaitu perubahan fiskal baik terhadap masyarakat dan perusahaanya. Menurut Desta (2016), Eksternalitas dari sebuah perusahan biasanya bersifat positif dan negatif seperti penyerapan tenaga kerja dan dampak limbah perusahaan tersebut. Menurut Oktabriani (2018), Eksternalitas bedasarkan ekonomi islam yaitu perusahaan yang menerapkan prinsip keadilan dan tolong menolong dan memberikan dampak eksternalitas dalam dalam bidang ekonomi, sosial dan kesehatan. Menurut Rahmadhani (2016), Dampak eksternalitas positif terhadap masyarakat dapat di lihat pada sekitarnya dengan meningkatkan standar hidup, pendapatan, pembangunan infastruktur, peluang pekerjaan hingga kemakmuran. Menurut Fathurrozi (2016), Dampak dari industry menciptakan ekternalitas terhadap perkembangan ekonomi masyarakat, kesejahteraan sosial dan lingkungan namun juga menciptakan eksternalitas negatif terhadap pencemaran lingkungan.

Menurut Marennu (2019), Pelaksanaan kebijakan mengenai pertambangan batu bara apabila di laksanakan dengan sungguh-sungguh maka akan banyak memberikan dampak positif namun dalam pelaksanaanya justru lebih mengarah ke dampak negatif seperti 
pencemaran lingkungan, banjir, polusi udara hal tersebut terjadi karena pemerintah tidak berpihak terhadap kepentingan dan kebaikan masyarakat. Menurut Mursyidin dan Warnida (2016), Dalam melaksanakan kegiatan pertambangan batu bara haruslah memperhatikan aspek kesehatan masyarakat yang berada di lingkungan sekeliling pertambangan. Menurut Ennandrianita (2014), Dalam menjalankan pertambanganya perlulah memperhatikan hukum dan regulasi yang mengatur dimana peran pemerintah haruslah kuat dalam hal ini seperti pengelolaan, pembinaan dan pengawasan. Menurut Suharto et al (2015), Dampak yang di timbulkan oleh pertambangan batu bara bersifat nyata yang pada umumnya lebih terlihat dampak negatif yang dapat langsung di rasakan oleh masyarakat yang biasanya bersifat sustainable dan dampak positif tidak langsung yang di terima oleh masyarakat biasanya bersifat tidak sustainable karena jika pertambang tersebut di hentikan maka dampak positif ini pun akan hilang. Menurut Lathif (2017), Dalam memberikan perizinan pertambangan pemerintah pusat dan provinsi memliki kontrol kuat dalam hal pengawasan.

Menurut Haryadi (2017), Pertambangan batu bara haruslah menggunakan strategi SO yaitu dengan memberdayakan kekuatan Sumber daya manusianya (SDM) yang berkualitas dan professional di tambah penggunakan teknologi yang modern untuk membantu perekonomian daerah atau masyarakat dalam memanfaatkan sumber daya alam (SDA) yang tersedia. Menurut Pratama (2018), Dalam penataan pertambangan perlunya control tata kelola yang baik karenya perlunya konsistensi, kekuatan hukum dan politik yang kuat dalam konteks pengetahuan untuk menciptakan perkembangan ekonomi yang baik, adil dan berkelanjutan.

Menurut Veronika (2015), Dalam meningkatkan sosial ekonomi masyarakat dimana seluruh kalangan masyarakat harus merasakan imbas atau dampak dari industry tersebut seperti peluang tenaga kerjaan guna meningkatkan pendapatan masyarakat, meningkatkan daya beli, kecukupan hidup dan menumbuhkan bisnis, guna menciptakan kemandirian sosial ekonomi di masyarakat. Menurut Andiani (2019), Dalam penelitian mengatakan bahwasanya munculnya sebuah industri di kalangan masyarakat dapat mempengaruhi sosial ekonomi masyarakat akan mpengaruh dari sebuah industri terhadap sosial ekonomi masyarakat sehingga pihak industri harus memperhatikan aspek ekonomi masyarakat dengan memberikan peluang pekerjaan bagi masyarakat. Menurut Apriyanto dan Harini (2012), Dampak peningkatan sosial ekonomi dari 
pertambangan batu bara dapat menimbulkan migrasi, menimbulkan konflik, dan menimbulkan peluang usaha.

\section{KAJIAN TEORI}

\section{Eksternalitas Positif}

Eksternalita positif adalah dampak seseorang atau perusahaan yang memberikan manfaat terhadap orang lain dan yang menerima manfaat tidak membayar atau memberikan harga atas manfaat yang diterima maka nilai yang ada dari dampak tersebut tidak tergambarkan dalam kegiatan pasar (Prasetyia, 2013). Hal tersebut juga Nampak pada sektor pertambangan batubara yang ada di Kabupaten Kutai Kartanegara secara tidak langsung perusahaan pertambangan yang berada di Kabupaten Kutai Kartanegara banyak memberikan externalitas positif kepada lingkungan masyarakat yang ada di sekitar pertambangan dan juga memberikan exsternalitas positif kepada daerah yang menjadi tempat produksi pertambangan.

\section{Dampak Sosial Ekonomi}

Status sosial ekonomi adalah keduduakan suatu individu atau keluarga bedasarkan unsur-unsur ekonomi Soekanto, 2007 dalam Ramadhanti, n.d (2016) dan menurut Fs Chapin berpendapat status sosial ekonomi ialah posisi pendapatan ekonomi individu atau keluarga bedasarkan ukuran rata-rata dan bedasarkan pendapatan efektif, aktifitas kelompok dan partisipasi (Kaare, 1989).

Sektor pertambangan batubara yang ada di kabupaten kutai kartanegara sangatlah memiliki pengaruh besar bagi masyarakat individu atau kelompok yang berada di lingkungan sekitar pertambangan khususnya dalam bidang sosial ekonomi. Karena kebanyakan masyarakat yang berada di lingkungan pertambangan batubara mata pencarianya ialah bekerja sebagai karyawan perusahaan atau berdagang UMKM.

\section{Kehidupan Sosial Ekonomi}

Sebuah kehidupan sosial ekonomi masyarakat sangat di pengaruhi oleh individu satu dengan individu lainya. Sperti kehidupan sosial ekonomi menurut sztomka 2005 dalam (Mansyah, 2013). Kehidupan sosial memiliki sebuah ke khasan tersendiri yaitu kesatuan yang mengandung proses dan hubungan timbal balik antara individu atau kelompok. Sepertihalnya 
yang terjadi di lingkungan pertambangan batubara di kabupaten kutai kartanegara yang dimana terdapat hubungan timbal balik yang terjadi antara pihak perusahaan dan masyarakat setempat.

\section{METODE PENELITIAN}

Metode yang di gunakan dalam penelitian ini menggunakan tipe dan jenis penelitian kualitatif dengan pendekatan deskriptif. Menurut Sugiyono dalam Wulandari et al (2019) Pendekatan kualitatif ialah pendekatan yang memberikan pemahaman dan gambaran yang jelas tentang objek atau fenomena yang ingin diteliti, berlandaskan pada filsafat postpositivisme, digunakan dalam meniliti objek yang alamiah, peneliti menjadi kunci instrument, teknik pengumpulan data dilakukan dengan cara triangulasi (gabungan), analisis data bersifat induktif atau kualitatif, dan hasil penelitian kualitatif lebih menekankan makna dari pada generalisasi.

Dalam penelitian ini peneliti menggunakan metode kualitatif deskriptif karena peneliti ingin melihat dan mengungkap realitas yang sebenarnya yang terjadi dilapangan yang berkaitan dengan dampak dari perusahaan pertambangan batubara terhadap sosial ekonomi masyarakat yang berada dilingkungan sekitar pertambangan di Kabupaten Kutai Kartanegara. Peneliti memilih problem tersebut dikarenakan banyaknya stigma negatif yang timbul dikalangan masyarakat terhadap perusahaan pertambangan batubara yang ada dilingkungan masyarakat, sehingga peneliti ingin mencari tahu keadaan sebenarnya yang ada di lapangan dan peneliti memilih lokasi penelitian di Kabupaten Kutai Kartanegara dikarenakan Kabupaten Kutai Kartanegara merupakan daerah penghasil batubara terbesar di Provinsi Kalimantan Timur dan merupakan salah satu daerah yang banyak terdapat perusahaan tambang batubara yang memiliki IUP (izin usaha pertambangan). Teknik pengumpulan data yang peneliti gunakan ialah teknik triangulasi dari beberapa sumber seperti jurnal dan buku lalu dilakukan analisis agar mendapatkan data yang akurat dan tepat. Penelitian ini dilakukan pada bulan juni-mei tahun 2020.

\section{PEMBAHASAN}

A. Dampak Sosial Oleh Perusahaan Pertambangan Batubara

Keberadaan sebuah perusahaan pastilah akan memberikan dampak terhadap lingkungan sekitarnya baik dampak postif ataupun dampak negatif. Seperti adanya dampak dalam bidang sosial, dimana sosial masyarakat yang berada di sekitar perusahaan pasti akan 
terkena dampaknya baik secara langsung ataupun tidak langsung. Seperti halnya yang terjadi di Kabupaten Kutai Kartanegara dimana banyak sekali terdapat perusahaan pertambangan batubara yang berjumlah 625 IUP (izin usaha pertambangan) tambang batubara (Ghofar, 2017). Dengan jumlah perusahaan yang sebanyak itu pastinya sektor pertambangan batubara di Kabupaten Kukar Kartanegara memberikan dampak yang sangat berpengaruh terhadap sosial lingkungan masyarakat yang berada di sekitarnya pertambangan batubara.

Dampak pertama ialah banyaknya warga yang tinggal didekat lingkungan pertambangan batubara lebih di dominasi oleh masyarakat transmigran yang berasal dari pulau jawa, 32,5 \% bekerja sebagai wiraswasta lebih banyak 12\% dibandingkan dengan penduduk asli, namun jika dilihat dalam pekerjaan sebagai aparatur negara (PNS) maka penduduk asli lebih dominan. Dengan adanya pertambangan batubara $\pm 38 \%$ masyarakat berpendapat bahwasanya semakin terbukanya lapangan pekerjaan di daerah mereka (Suharto et al., 2015). Sehingga seiring berkembangnya nilai perekonomian di daerah tersebut menyebabkan adanya transisi mata pencarian yang dilakukan masyarakat sekitar yang awalnya petani, wirausaha, dan lain-lain beralih menjadi menjadi karyawan pertambangan yang dimana pendapatanya jauh lebih besar.

Dampak secara langsung yang di dapat dengan adanya perusahaan pertambangan batubara tidak hanya dapat membuka peluangan pekerjaan yang luas namun ada juga dampak secara tidak langsung yang ditimbulkan, ialah dimana pertambangan batubara menjadi sektor pendukung perekonomian lokal seperti semakin ramainya penduduk yang berwirausaha misalnya warung sembako, warung makan, kios, bengkel, jasa parkir motor dan masih banyak lagi (lihat gambar 1). Meningkatnya wirausaha dilingkungan masyarakat karena mulai ramainya permintaan pelayanan tersebut, berbeda dengan sebelum adanya perusahaan pertambangan batubara didaerah mereka. Adapun faktor penunjang yang diberikan perusahaan kepada masyarakat dengan pembangunan infastruktur antara lain seperti pembangunan posyandu, pos kamling, rumah ibadah, sarana olahraga dan masih banyak lagi (Mansyah, 2013).

Perubahan sosial yang terjadi masyarakat tidak hanya terjadi ketika proses pertambangan berlangsung. Pemanfaatan lahan pasca tambangpun masih dapat di lakukan oleh 
masyarakat. Seperti halnya mengubah lahan pasca tambang menjadi lahan yang potensial seperti perkebunan, peternakan ikan, hingga pembangunan (Bintoro, n.d.). Terdapat perubahan sosial seperti mata pencarian dan pembangunan yang terjadi di masyarakat setelah pasca penambangan itu sendiri. Hal tersebut pastinya sangat membantu menigkatkan kesejahteraan masyarakat dalam bentuk sosial.

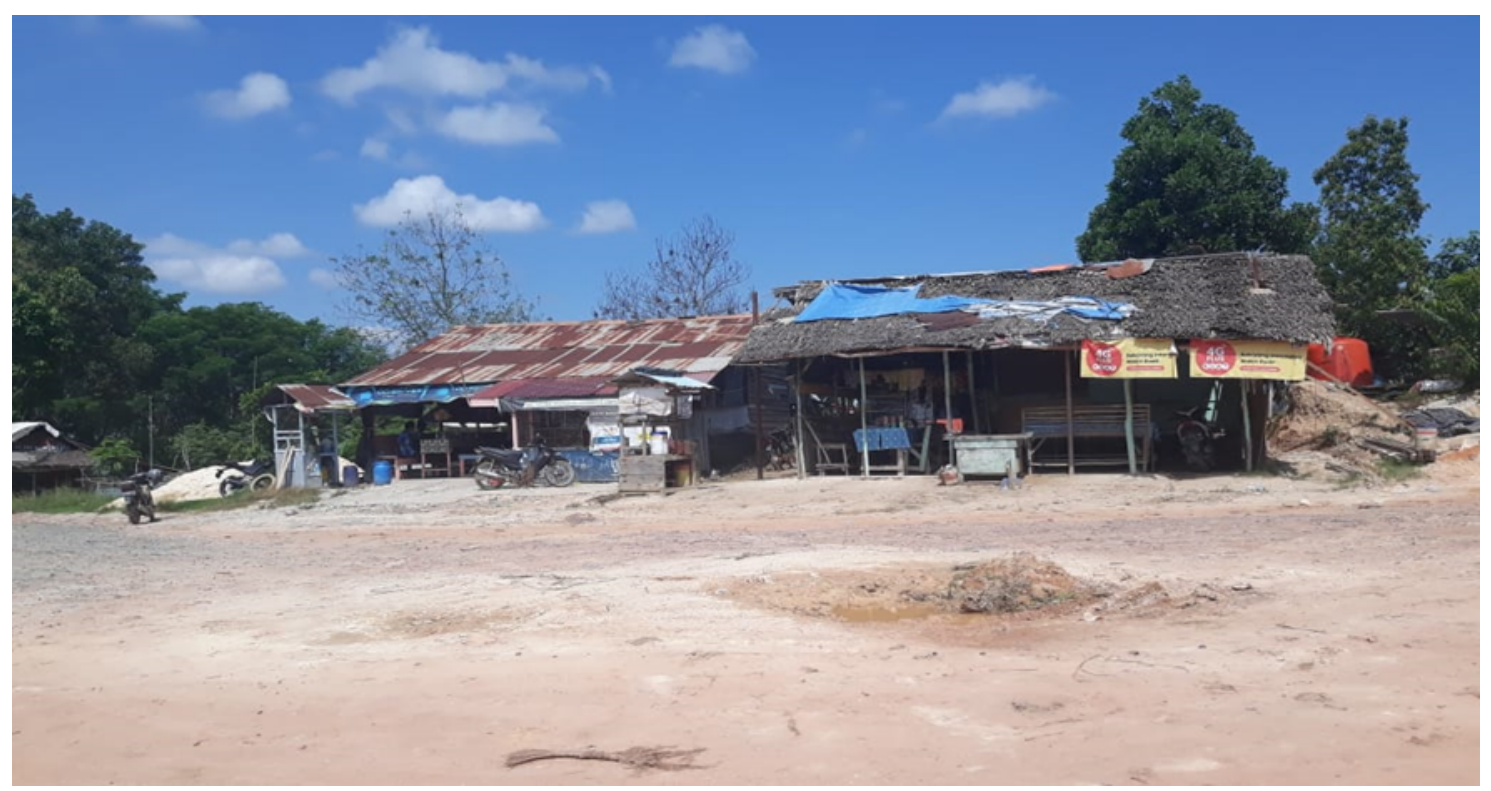

Gambar 1.

Foto Salah satu Usaha Warung Kopi Milik Masyarakat di Sekitar Lingkungan Pertambangan Sumber: Warung Usaha di kecamatan Muara jawa, Kabupaten Kutai Kartanegara, 2019.

Sehingga dalam kehidupan sosial yang berlangsung terdapat hubungan timbal balik antara pihak perusahaan dengan masyarakat yaitu seperti, semakin luasnya peluangan pekerjaan bagi masyarakat, bantuan sosial, pembangunan hingga reklamasi pasca tambang menjadi peluang usaha bagi masyarakat (Jiuhardi, 2012).

B. Dampak Ekonomi Oleh Perusahaan Tambang Batubara

Bidang Ekonomi adalah salah satu bidang yang harus diperhatikan di suatu daerah. Karena bidang ekonomi sendiri menjadi tolakukur penilaian kesejahteraan dalam suatu daerah, 
baik ekonomi masyarakatnya ataupun daerahnya. Keberadaan sebuah perusahaan dalam suatu lingkungan atau daerah akan memberikan pengaruh terhadap perekonomianya daerah tersebut. Seperti perusahaan tambang batubara yang ada di Kutai Kartanegara menjadi sektor penyumbang terbesar bagi perekonomian daerah tersebut. Bedasarkan harga konstan 2010 nilai produk Domestik Regional Bruto Kabupaten Kutai Kartanegara mengalami peningkatan pada tahun 2019. Peningkatan tersebut terjadi karena adanya peningkatan produksi di setiap lapangan usaha yang terhindar dari pengaruh inflasi. Nilai Produk Domestik Regional Bruto Kabupaten Kutai Kartanegara (PDRB) atas dasar harga konstan 2010 pada tahun 2018 sebesar 121,46 triliun rupiah dan naik menjadi 126,04 triliun rupiah pada tahun 2019. Sehingga dapat dilihat pada tahun 2019 menunjukan pertumbuhan ekonomi sebesar 3,77\% (Purbondari \& Dewi Intansari, 2020).

PDRB perkapita Kabupaten Kutai KartaNegara bedasarkan harga berlaku sejak tahun 2015 sampai 2019 mengalami kenaikan. Pada tahun 2015 PRDB perkapita Kutai KartaNegara tertilis sebesar 117,14 Juta rupiah, nilai tersebut mengalami penurunan sampai tahun 2016 menjadi 173,97 juta rupiah. Lalu pada tahun 2017 sampai tahun 2018 kembali mengalami kenaikan dari 198,41 menjadi 210,48 juta rupiah dan mengalami penurunan kembali pada tahun 2019 menjadi 207,02 juta rupiah (lihat tabel 1). Pada tahun 2017 PDRB per kapita cukup tinggi, hal tersebut di pengaruhi oleh faktor meningkatnya harga batubara yang merupakan komoditas yang mendominasi perekonomian di Kabupaten Kutai Kartanegara sehingga berdampak terhadap kenaikan nilai PDRB perkapita di Kabupaten Kutai Kartanegara (Purbondari \& Dewi Intansari, 2020).

Pada tahun 2017 pula Kabupaten Kutai kartanegara menjadi daerah yang memproduksi batubara terbanyak di Provinsi Kalimantan Timur yaitu sebesar 82,87 juta ton dari total produksi perusahaan pemegang izin usaha pertambangan (IUP) dan pada tahun 2018. Kabupaten Kutai Kartanegara memproduksi batubara naik mencapai 86,989,488.38 per metrix ton (MTon) (Badan pusat Statistik, kabupaten kutai kartanegara 2019). Kabupaten Kutai Kartanegara menerima Dana Bagi Hasil (DBH) batubara terbesar kedua di provinsi kaltim dengan jumlah Rp2,860 triliun (Intoniswan, 2020). 
Tabel 1.

Produk Domestik Regional Bruto dan PDRB Perkapita Kabupaten Kutai Kartanegara,

2015-2019

\begin{tabular}{|c|c|c|c|c|c|}
\hline Indikator / Indicators & 2015 & 2016 & 2017 & $2018^{*}$ & $2019 * *$ \\
\hline (1) & (2) & (3) & (4) & (5) & (6) \\
\hline \multicolumn{6}{|l|}{$\begin{array}{l}\text { Nilai PDRB/ GRDP (Juta } \\
\text { Rupiah/Million Rupiah) }\end{array}$} \\
\hline - $\mathrm{ADHB} /$ at Current Price & $127.151,49$ & $127.869,34$ & $149.220,00$ & $161.933,47$ & $162.739,38$ \\
\hline - $A D H K /$ at 201 Constant Price & $119.388,78$ & $117.035,58$ & $118.943,99$ & $121.461,42$ & $126.042,29$ \\
\hline \multicolumn{6}{|c|}{ PDRB per Kapita/Per Capita GRDP (Ribu Rupiah/Thousand Rupiah) } \\
\hline - $\mathrm{ADHB} /$ at Current Price & $177.143,27$ & $173.968,11$ & $198.406,84$ & $210.484,44$ & $207.015,42$ \\
\hline - $A D H K /$ at 201 Constant Price & $166.328,52$ & $159.228,61$ & $158.151,06$ & $157.878,05$ & $160.334,26$ \\
\hline $\begin{array}{l}\text { Pertumbuhan PDRB per } \\
\text { Kapita ADHK 2010/ } \\
\text { Growth of Per Capita GRDP at } \\
\text { 2010 Constant Price }\end{array}$ & $-2,89$ & $-0,82$ & 0,70 & 0,92 & 1,73 \\
\hline $\begin{array}{l}\text { Jumlah Penduduk (jiwa)/ } \\
\text { Population (People) }\end{array}$ & 717.789 & 735.016 & 752.091 & 769.337 & 786.122 \\
\hline $\begin{array}{l}\text { Pertumbuhan Jumlah Penduduk } \\
\text { (Persen)/ Population Growth } \\
\text { (Percent) }\end{array}$ & 2,48 & 2,40 & 2,32 & 2,29 & 2,18 \\
\hline
\end{tabular}

Angka sementara/Preliminary Figures

**Angka sangat sementara/Very Preliminary Figures

Sumber: https://kukarkab.bps.go.id/ 2019.

Kontribusi sektor pertambangan batubara sendiri dalam pembentukan PDRB Kabupaten Kutai Kartanegara masih tingg dalam jangka waktu 5 (lima) tahun terakhir. Nilai kontribusinya sebesar 86,19\% tahun 2015 menjadi 102,24 triliun rupiah atau sekitar 62,82\% hingga tahun 2019. (dilihat Grafik 1). 


\section{Grafik 1}

Peranan Kategori Terhadap PDRB dan Laju Pertumbuhan Kategori Pertambangan dan Penggalian di Kabupaten Kutai Kartanegara (persen), 2015-2019.

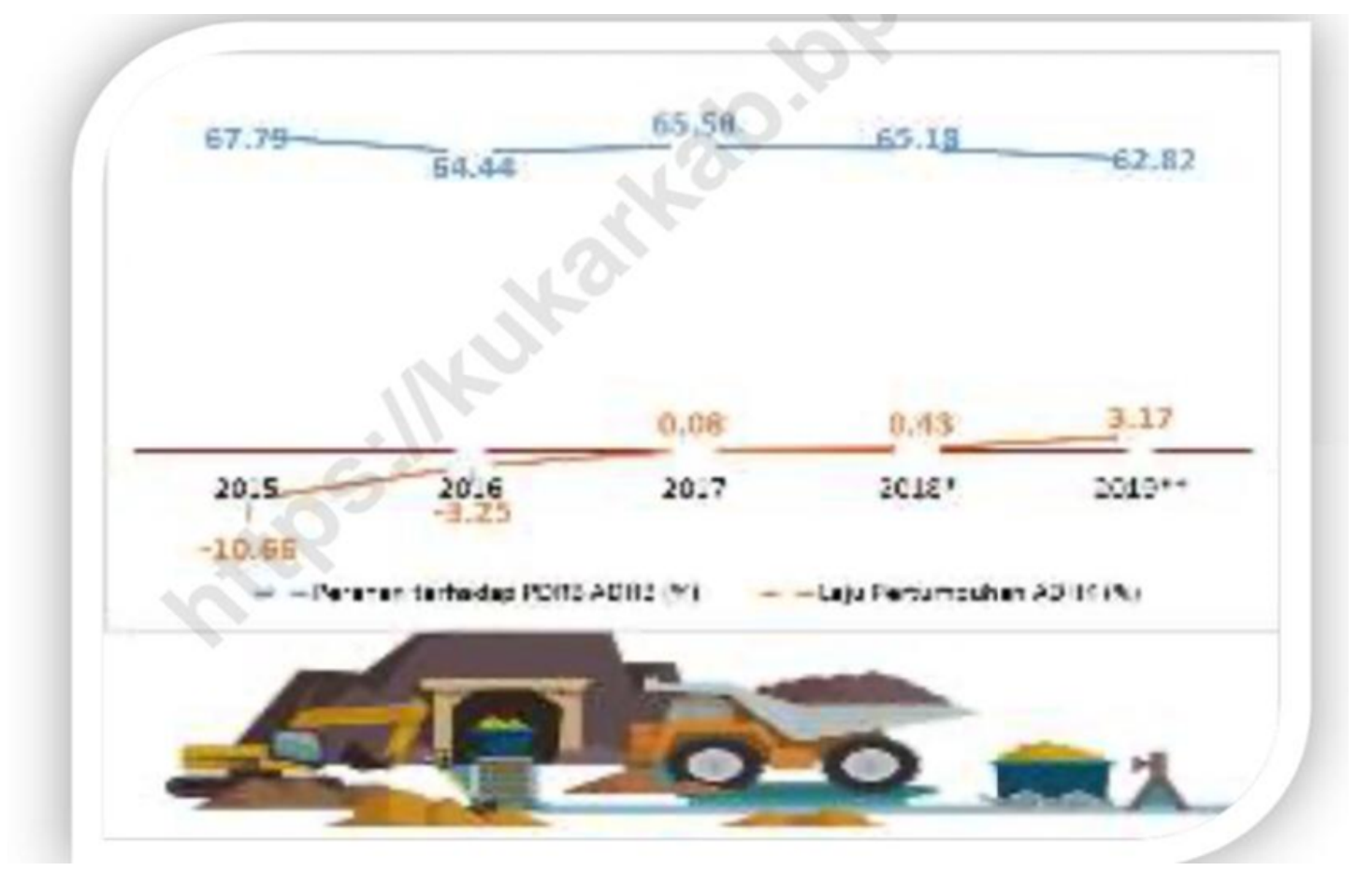

Sumber; https://kukarkab.bps.go.id/ 2019.

Dari data di atas dapat kita lihat bahwasanya adanya perusahaan pertambangan batubara di Kabupaten Kutai Kartanegara sangat mempengaruhi atau berdampak terhadap pertumbuhan Ekonomi di daerah tersebut. Tidak hanya ekenomi daerahnya saja yang terdampak namun ekonomi lokal atau masyarakatnya juga terkena dampak tersebut. yaitu semakin meluasnya peluang pekerjaan yang tercipta akibat dampak tambang batubara di lingkungan sekitar seperti wirausaha dan karyawan swasta, sehingga meningkatkan pendapatan perkapita masyarakatnya. Seperti contoh perekrutan tenaga kerja yang di butuhkan oleh perusahaan PT. Anggana Coal yang berada di Kecamatan Loa Kulu, Kabupaten Kutai Kartanegara (dilihat gambar 2). 


\begin{tabular}{|c|c|c|}
\hline No. & Deskripsí Kebutuhan Tenaga Kerja & Jumlah (orang) \\
\hline A & Manajemen & \\
\hline 1 & Project Manager & 1 \\
\hline 2 & Mine Manager & 1 \\
\hline 3 & Plant \& Machinery Manager & 1 \\
\hline 4 & Mine Operation Manager & 1 \\
\hline 5 & Safety Manager & 1 \\
\hline 6 & Marketing Manager & 1 \\
\hline 7 & Coal Prep. Plant Manager & 1 \\
\hline 8 & Finance \& Administrasi Manager & 1 \\
\hline \multirow[t]{2}{*}{9} & Secretary & 1 \\
\hline & Jumlan & 9 \\
\hline $\mathbf{B}$ & K3 dan Coorporate Social Responsibity (CSR) & \\
\hline 1 & HRD & 2 \\
\hline 2 & Accountant & 2 \\
\hline 3 & Administration Personil & 3 \\
\hline 4 & Information Tech. Engineer & 1 \\
\hline \multirow[t]{2}{*}{5} & Staff $\mathrm{K3}$ & 1 \\
\hline & & 9 \\
\hline $\mathbf{B}$ & K3 dan Coorporate Social Responsibity (CSR) & \\
\hline 6 & Staff Community Development/CSR & 1 \\
\hline 7 & Staff Lingkungan & 1 \\
\hline 8 & Secretary & 1 \\
\hline 9 & Security Guard & 6 \\
\hline 10 & Tenaga Medis (dokter) & 1 \\
\hline
\end{tabular}

\begin{tabular}{|c|c|c|}
\hline 11 & Paramedis (perawat) & 2 \\
\hline & Jurniah : & 12 \\
\hline \multirow[t]{3}{*}{ C } & Perencanaan dan Enggineering & \\
\hline & $\begin{array}{l}\text { Mine Engineer } \\
\text { Safety Personil } \\
\text { Projek Engineer } \\
\text { Geologist } \\
\text { Computer Analist } \\
\text { Technical Drafting } \\
\text { Surveyor } \\
\text { Secretary } \\
\text { ClerkfHelper Surveyor }\end{array}$ & $\begin{array}{l}2 \\
3 \\
1 \\
1 \\
1 \\
1 \\
2 \\
1 \\
2\end{array}$ \\
\hline & Jumlah : & 14 \\
\hline $\mathbf{D}$ & Administrasi dan Keuangan & \\
\hline $\begin{array}{l}1 \\
2 \\
3\end{array}$ & $\begin{array}{l}\text { Accounting Staff } \\
\text { Secretary } \\
\text { Clerk }\end{array}$ & $\begin{array}{l}1 \\
1 \\
1\end{array}$ \\
\hline 3 & Jumlah : & 3 \\
\hline$E$ & Operasi & \\
\hline $\begin{array}{l}1 \\
2 \\
3 \\
4 \\
5\end{array}$ & $\begin{array}{l}\text { Production Surveyor } \\
\text { Foreman } \\
\text { Heavy Equipment Operator } \\
\text { Ligh Equipment Operator } \\
\text { Cheker }\end{array}$ & $\begin{array}{l}1 \\
3 \\
44 \\
10 \\
6\end{array}$ \\
\hline 5 & Jurniah : & 65 \\
\hline $\mathbf{F}$ & Perawatan Dan Logistik & \\
\hline $\begin{array}{l}1 \\
2 \\
3 \\
4 \\
5 \\
6\end{array}$ & $\begin{array}{l}\text { Engineer } \\
\text { Mechanics } \\
\text { Electrician } \\
\text { Welder } \\
\text { Parts Counter } \\
\text { Unskilled Laborer }\end{array}$ & $\begin{array}{c}2 \\
4 \\
2 \\
3 \\
4 \\
12\end{array}$ \\
\hline 6 & Jumlah : & 27 \\
\hline $\mathbf{G}$ & CPP & \\
\hline $\begin{array}{l}1 \\
2 \\
3 \\
4 \\
5 \\
6\end{array}$ & $\begin{array}{l}\text { Kepala Bagian } \\
\text { Teknisi } \\
\text { Staff adminsitrasi } \\
\text { Enggineering dan Analist } \\
\text { Quality Control } \\
\text { Helper }\end{array}$ & $\begin{array}{l}1 \\
4 \\
4 \\
1 \\
1 \\
4\end{array}$ \\
\hline & Jumlah : & 15 \\
\hline & Jumlah Total : & 151 \\
\hline
\end{tabular}

Gambar 2. Rekrutmen Tenaga Kerja Oleh PT Anggana Coal.

Sumber: PT. Anggana Coal,2010. 
Dapat di lihat di atas bahwasanya oprasional perusahaan tambang batubara yaitu PT.Anggana Coal membutuhkan 151 pegawai atau karyawan yang berarti semakin peluang pekerjaan bagi masyarakat sekitar, meningkatkan pendapatan perkapita masyarakat serta semakin meminimalisir tingkat pengangguran yang ada di Kabupaten Kutai Kartanegara. Adapun jumlah peluang pekerjaan di sektor pertambangan berada di posisi ke 3 (tiga) dengan jumlah $14.86 \%$ setelah sektor perdagangan dengan jumlah $21.65 \%$ dan sektor pertanian dengan jumlah 28.83\% (dilihat di Gambar 3). Dapat dilihat adanya bahwa peluang pekerjaan yang dimiliki masyarakat di Kabupaten Kutai Kartanegara dengan adanya sektor pertambangan batubara semakin meluas.

Ditambah dilihat kondisi pada saat ini bahwasanya sebagian besar masyarakat Kabupaten Kutai Kartanegara memiliki status pekerjaan utama yaitu sebagai Buruh/Pegawai/Karyawan dengan jumlah 48,59\% (dilihat pada gambar 4), paling tinggi dibandingkan dengan pekerjaan utama di sektor lainya.

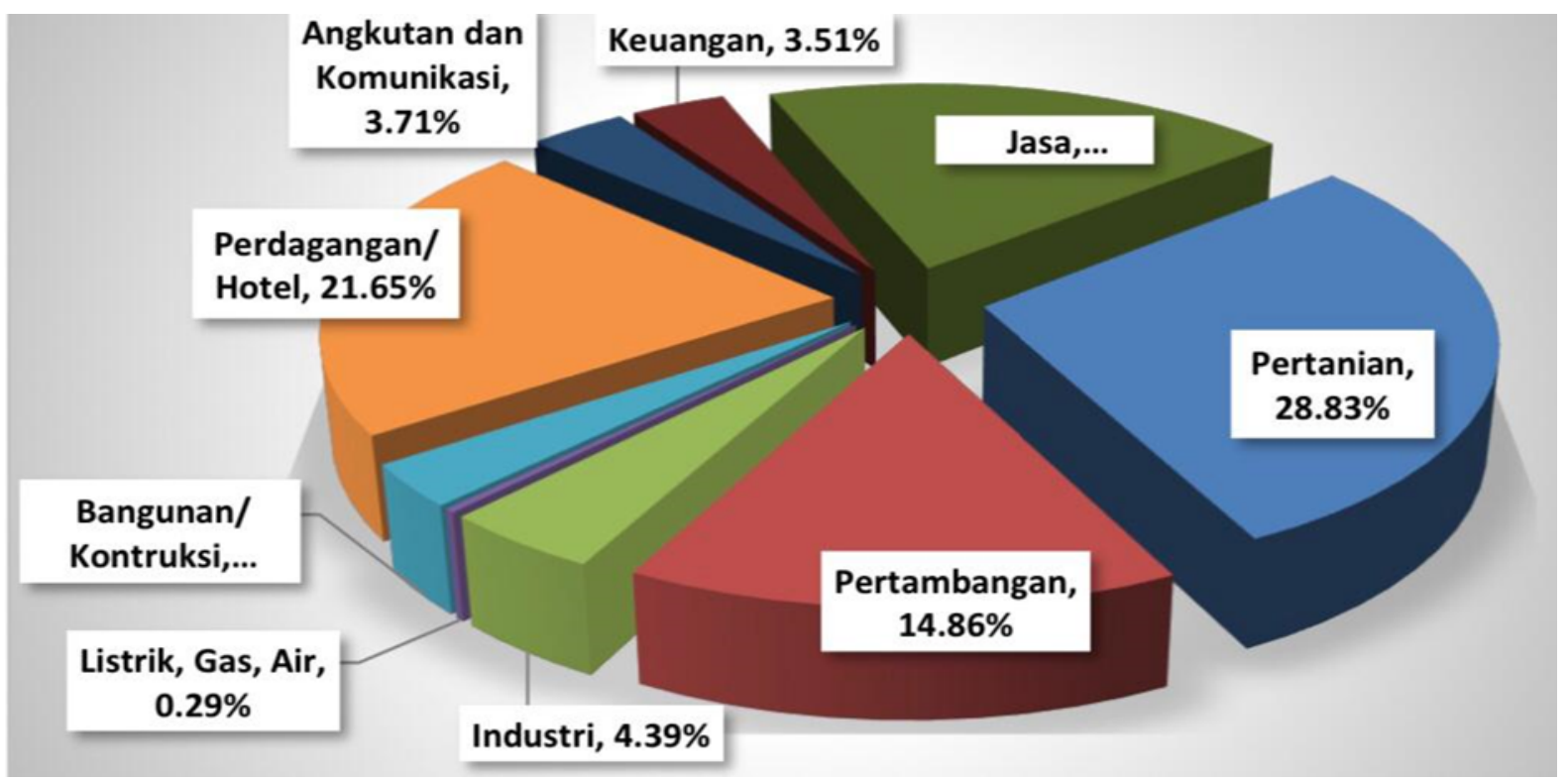

Gambar 3.

Persentase Penduduk Berumur 15 Tahun ke Atas yang Bekerja Menurut Lapangan Pekerjaan Utama, 2018.

Sumber: https://kukarkab.bps.go.id/ 2019. 


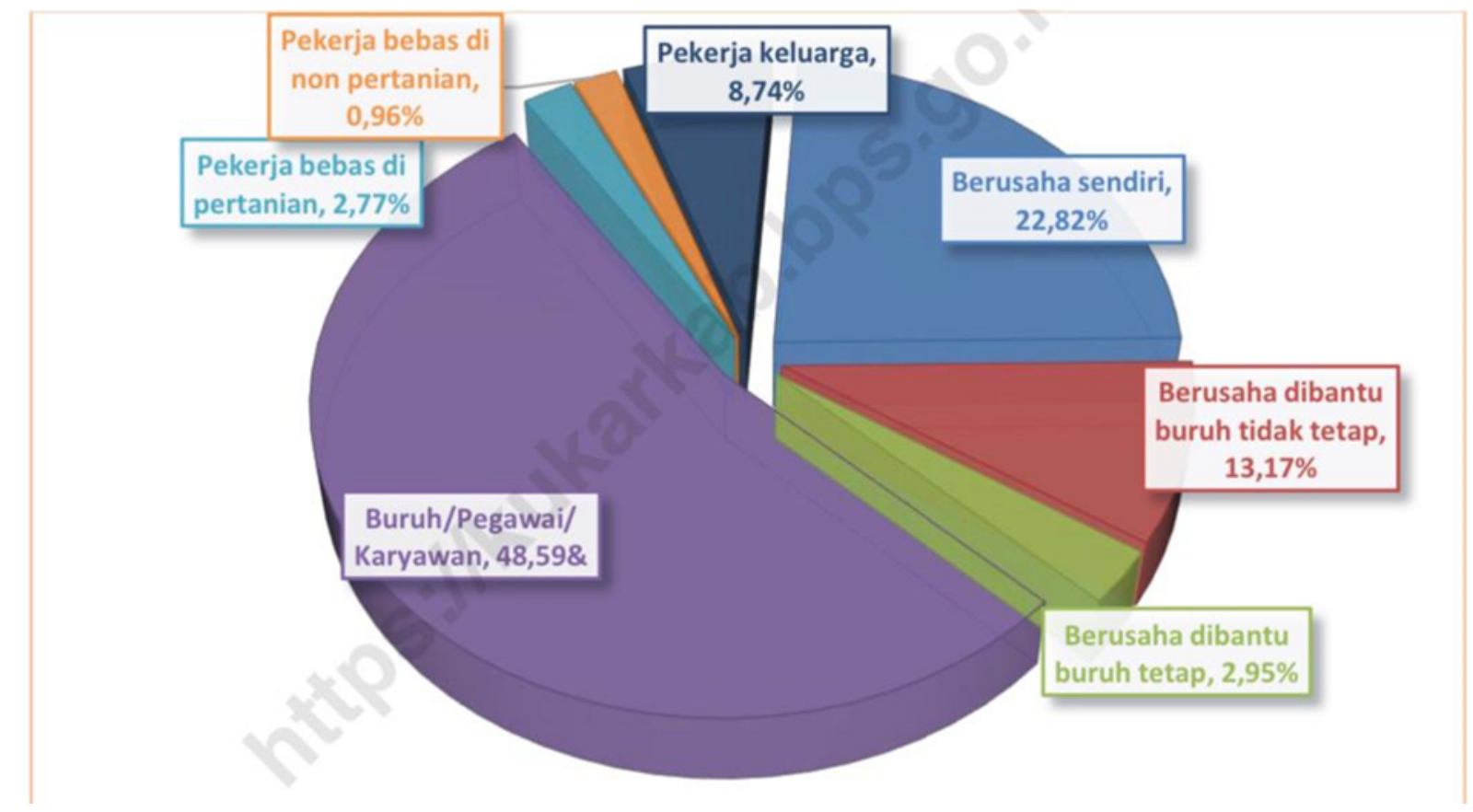

Gambar 4

Persentase Penduduk Berumur 15 Tahun ke Atas yang Bekerja Menurut Status Pekerjaan Utama, 2018.

Sumber: https://kukarkab.bps.go.id/ 2019.

\section{KESIMPULAN}

Bedasarkan beberapa uraian di atas penulis menarik kesimpulan bahwasanya, dengan hadirnya perusahaan tambang batubara di Kabupaten Kutai Kartanegara secara langsung ataupun tidak langsung dapat memberikan dampak positif terhadap Sosial Ekonomi Masyarakat. Seperti semakin meningkatnya jumlah penduduk di lingkungan pertambangan batubara yang berasal dari pulau yang menyebabkan semakin ramainya peluang usaha milik masyarakat (UMKM), semakin meningkatnya kegiatan-kegiatan sosial dimasyarakat seperti ibadah, pendidikan, posyandu, poskamling, dll, dikarenakan adanya faktor penunjang yang di ciptakan oleh perusahaan tambang batubara dalam bidang pembangunan infastruktur, semakin meningkatnya peluang pekerjaan bagi masyarakat sekitar sehingga dapat meningkatkan perekonomian masyarakat ataupun daerah di sebabkan oleh sektor tambang yang menjadi n 
komoditas yang mendominasi dalam bidang ekonomi di Kabupaten Kutai Kartanegara. Sehingga dengan pertumbuhan ekonomi tersebut dapat menjadi penunjang kesejahteraan masyarakat sekitar.

Adapun saran yang peneliti berikan antara lain, Saran untik masyarakat ialah subsidi ataupun dampak positif yang di berikan oleh perusahaan pertambangan sebaiknya digunakan dan dimanfaatkan dengan baik, karena perusahaan pertambangan batubara sendiri merupakan perusahaan yang jangka panjang atau berkelanjutan sehingga masyarakat Kabupaten Kutai Kartanegara tidak kebingungan lagi ketika perusahaan Tambang batubara tidak lagi beroprasi di daerah tersebut. Lalu saran buat sektor pertambangan sendiri ialah, selain memberikan bantuan berupa Objek (infastruktur) dan Ekonomi (Dana) sebaiknya juga memberikan pemberdayaan kepada masyarakat sekitar baik asli ataupun tranmigran. Sehingga menciptakan kemandirian serta pengetahuan yang baik agar tidak ketergantungan terhadap sebuah perusahaan.

\section{DAFTAR PUSTAKA}

Bintoro, A. (n.d.). Diskusi IKN, Bupati Kukar Yakin Lahan Tambang Tak Ekonomis Potensial Dukung Ibu Kota Nugara Artikel ini telah tayang di tribunkaltim.co dengan judul Diskusi IKN, Bupati Kukar Yakin Lahan Tambang Tak Ekonomis Potensial Dukung Ibu Kota Nugara, https://kalti. Retrieved from https://kaltim.tribunnews.com/2019/11/13/diskusi-ikn-bupati-kukar-yakin-lahantambang-tak-ekonomis-potensial-dukung-ibu-kota-nugara

Andiani, F. (2019). PENGARUH KEBERADAAN INDUSTRI PT.

Apriyanto, D., \& Harini, R. (2012). Dampak Kegiatan Pertambangan Batubara Terhadap Kondisi Sosial-Ekonomi Masyarakat. Jurnal Bumi Indonesia, 1, 289-298.

Desta, W. S. (2016). ANALISIS EKSTERNALITAS PT. FERMENTECH INDONESIA TERHADAP TINGKAT PENDAPATAN DAN PENYERAPAN TENAGA KERJA MASYARAKAT DESA GUNUNG PASIR JAYA LAMPUNG TIMUR, 1-10. 
Fathurrozi, F. (2016). Eksternalitas Industri di Kota Probolinggo.

Ferdricka Nggeboe.SH, M. (2004). Dampak Sosial Ekonomi Penambangan Batubara, 4351.

Ferry Prasetyia, SE., Ma. (2013). BAGIAN V: Dosen: Ferry Prasetyia FAKULTAS EKONOMI DAN BISNIS. Retrieved from http://ferryfebub.lecture.ub.ac.id/files/2013/01/BagianV-Teori-Eksternalitas.pdf

Fine Ennandrianita. (2014). POLITIK HUKUM PERTAMBANGAN MINERAL DAN BATUBARA SAAT BERLAKU UNDANG-UNDANG NOMOR 23 TAHUN 2014

TENTANG PEMERINTAHAN DAERAH. Journal of Chemical Information and Modeling, 6. https://doi.org/10.1017/CBO9781107415324.004

Haryadi, H. (2017). Analisis SWOT dalam pengelolaan sumberdaya mineral dan batubara Indonesia serta prospeknya dalam menghadapi masyarakat ekonomi asean (MEA). Jurnal Teknologi Mineral Dan Batubara, 13(1), 73-90. https://doi.org/10.30556/jtmb.vol13.no1.2017.141

Hendry, D. (n.d.). Kerusakan Lingkungan Akibat Tambang Batubara Terus Berlanjut, Apa Solusinya. Retrieved from https://www.mongabay.co.id/2017/05/17/kerusakanlingkungan-akibat-tambang-batubara-terus-berlanjut-apa-solusinya/

Intoniswan. (2020). TAHUN 2020 SEMBILAN DAERAH DI KALTIM PANEN DBH BATUBARA RP9,435 TRILIUN. Retrieved May 7, 2020, from https://www.niaga.asia/wow-tahun-2020-sembilan-daerah-di-kaltim-panen-dbhbatubara-rp9435-triliun/.

Jiuhardi. (2012). Tanggung Jawab Sosial Dan Lingkungan Perusahaan Pertambangan Batu Bara Dalam Upaya Meningkatkan Kesejahteraan Masyarakat Kutai Kartanegara. Forum Ekonomi, XV(2), 13-28.

Kaare, 1989:26. (1989). Status Sosial Ekonomi. 
Lathif, N. (2017). TINJAUAN YURIDIS TENTANG KEWENANGAN PEMERINTAH PROVINSI DALAM PENERBITAN IZIN USAHA PERTAMBANGAN BATUBARA, 2(2), 149-166.

Mai Oni Sandra (Department of Agribusiness Faculty of Agriculture, U. of R. (2015). DAMPAK EKSTERNALITAS PABRIK PENGOLAHAN KELAPA SAWIT (PKS) PT. TAMORA AGRO LESTARI (TAL) TERHADAP SOSIAL EKONOMI MASYARAKAT DI DESA SEROSAH KECAMATAN HULU KUANTAN KABUPATEN KUANTAN SINGINGI, 2015(2), 1-6.

Mansyah, N. (2013). Studi Tentang Dampak Pertambangan Batu Bara Bagi Kehidupan Sosial Ekonomi Masyarakat Di Kelurahan Jawa Kecamatan Sangasanga. Administrasi Negara, 1(3), 843-857.

Marennu, S. A. (2019). Analisis Kebijakan Pemerintah Daerah Bidang Pertambangan di Kota Samarinda, 12, 21-32.

M Ghofar. (2017). Kutai Kartanegara Miliki Izin Pertambangan Terbanyak. Retrieved May 7 , 2020, from https://kaltim.antaranews.com/berita/38664/kutai-kartanegara-miliki-izinpertambangan-terbanyak

Mursyidin, \& Warnida, H. (2016). Persepsi Masyarakat Terhadap Dampak Kesehatan Dari Aktivitas Penambangan Batubara Di Kampung Tasuk Kabupaten Berau. Jurnal Ilmiah Manuntung, 2(2), 120-131.

Oktabriani, E. N. (2018). DAMPAK EKSTERNALITAS INDUSTRI PENGOLAHAN KARET TERHADAP KONDISI SOSIAL EKONOMI MASYARAKAT DALAM PERSPEKTIF EKONOMI ISLAM, (1). https://doi.org/.1037//0033-2909.I26.1.78

Pratama, S. (2018). DIMENSI EKONOMI POLITIK DALAM KONFLIK TATA KELOLA PERTAMBANGAN (Studi Kasus Surat Keputusan Gubernur Bangka Belitung Tentang Penghentian Sementara Operasional Pertambangan Laut PT Timah, Tbk Tahun 2016). Jurnal Wacana Politik, 3(1), 40-53. 
https://doi.org/10.24198/jwp.v3i1.16084

Purbondari, D., \& Dewi Intansari, S. S. (2020). PRODUK DOMESTIK REGIONAL BRUTO KABUPATEN KUTAI KARTANEGARA MENURUT LAPANGAN USAHA. $\begin{array}{llll}\text { Retrieved } & \text { May } & \text { 2020, from }\end{array}$ https://kukarkab.bps.go.id/publication/2020/04/30/27b86bb129fbc46ee895f489/produ k-domestik-regional-bruto-kabupaten-kutai-kartanegara-menurut-lapangan-usaha2015-2019.html

Rahmadhani, E. R. (2016). DAMPAK EKSTERNALITAS POSITIF PT.PETROKIMIA GRESIK TERHADAP MASYARAKAT DALAM PERSPEKTIF MAQASHID, 1-10.

Ramadhanti, D. (n.d.). PENGARUH STATUS SOSIAL EKONOMI ORANG TUA TERHADAP SIKAP KEWIRAUSAHAAN, 32-37.

Rikhza Hasan. (2019). 10 Negara Penghasil Batu Bara Terbesar di Dunia, Ada Indonesia. $\begin{array}{llll}\text { Retrieved } & \text { May } & \text { 7, 2020, }\end{array}$ https://economy.okezone.com/read/2019/01/31/320/2012015/10-negara-penghasilbatu-bara-terbesar-di-dunia-ada-indonesia

Suharto, R. B., Hilmawan, R., Yudaruddin, R., Ekonomi, F., Mulawarman, U., \& Timur, K. (2015). Sumber Daya Alam Untuk Kesejahteraan Penduduk Lokal: Studi Analisis Dampak Pertambangan Batu Bara Di Empat Kecamatan Area Kalimantan Timur, Indonesia. Jurnal Organisasi Dan Manajemen, 2, 127-137.

Veronika, V. (2015). Eksternalitas Industri Batu Bata Terhadap Sosial Ekonomi di Kecamatan Tenayan Raya. Jom Fekon, 2(2), 1-13. https://doi.org/10.1017/CBO9781107415324.004

Wulandari, W., Purnomo, E. P., Studi, P., Ilmu, M., Yogyakarta, U. M., Brawijaya, J., \& Yogyakarta, D. I. (2019). JURNAL ILMU PEMERINTAHAN Kajian Ilmu Pemerintahan dan Politik Daerah, 4(April), 2-3. 